\title{
The Portrait of High School Student Physics Competence with Vertical Equating Lens
}

\author{
Suhariyono Suhariyono*, Amat Jaedun
}

\author{
Universitas Negeri Yogyakarta, Indonesia \\ *Corresponding author. Email: suhariyono87@gmail.com
}

\begin{abstract}
This research aims reveal: (1) the vertical equating equation of a test instrument, and (2) the development of physics competence among grade X and XI students of senior high school. This study used the quantitative descriptive method. The population is the students of senior high schools in Purworejo district. The data are in the form of the students' responses to the reasoning ability tests on the physics subject. The research sample was established using the stratified proportional random sampling technique, consisting of 352 grade X students and 352 grade XI students. The instruments are two sets of physics tests in the form of objective tests with five alternative answer and using an anchor of $25 \%$. The data are in the form of a processed partition and equated using common item non-equivalent groups' designs with mean \& sigma equating methods based on the model of Rasch item theory. The research concluded that (1) the results of the vertical equation based on the Rasch model show that the equation for transition from type $\mathrm{X}$ to type XI is $b *=b x-0.36$; (2) there is an increase in the physical ability of students from grade X to grade XI or the ability of grade XI students is higher than that of grade X. The conclusion of this study can be used as an input for teachers. Improving themselves concerning the teaching that has been done and the achievement that has been made by paying attention to appropriate learning methods and student motivation to improve student physics learning achievement.
\end{abstract}

Keywords: Improving themselves, physic competence, vertical equating

\section{INTRODUCTION}

ASEAN Economic Community (AEC) has begun to take shape in 2015 [1]. It is a free trade system among ASEAN countries. The establishment of the AEC as a major milestone in the regional economic integration leads to the free flow of goods, services, capital, and labor in each ASEAN member countries. To succeed in passing through this era, Indonesia has undertaken various efforts, such as preparing excellent human resources to compete with workers from other countries. This means that quality education plays a vital role to prepare qualified humans of Indonesia.

The government has done many programs to improve the quality of education in Indonesia, like the 9-year compulsory education program listed in Law No. 20 of 2003 on national education. The compulsory education program states that every citizen aged 7-15 years is obliged to attend basic education. To overcome the problem of a 9-year compulsory education program for low-income communities, the government also provides financial assistance, namely BOS (Bantuan Operasional Sekolah/ School Operational Assistance) and scholarship programs for high-achieving students from a poor family.

If the quality of education is good, the development of technology can be increasing rapidly. One of the important knowledge for the development of technology in physics is because many new technologies are produced from this field. The physics subject includes in the curriculum of Indonesia, starting from junior high until the university level. In senior high school, physics is one of the subjects for the National Examination but not all students take these subjects because they may choose based on their specialization subjects. Yet, physics subjects are still considered difficult by some students. According to data [2], the results of the National Examination in 2015/2016 for this course show 
that the mean score was 44.49 and labelled in the $\mathrm{C}$ category.

Physics, as a science subject, can develop deductive thinking ability through various natural events in solving problems either qualitatively or quantitatively by using mathematics and developing knowledge, skills, and confidence[3]. This means that physics is one of the sciences that allows students to delve deeper into nature and whose interactions require thinking skills. Teaching thinking skills and incorporating them into learning materials can train students to be good thinkers.

Currently, the learning process does not support the development of students' analytical skills [4]. Since students act mostly as recipients of information from the teacher. Usually, the students learning activities are just listening and recording the teacher's explanation. Such learning processes make them lack analytical skills and problem-solving skills. Indeed, they should have analytical skills as supporting analysis to master reasoning skills. Developing their reasoning skills is intended to optimize their intellectual potential.

The research problem is the ability to reason physics in high school students in the form of multiple choice. In this case, the physical reasoning ability of grades $\mathrm{X}$ and XI students is different, but it is assumed to be the same. By having tests, people can reveal several things that may not be disclosed by other methods. Related to the importance of test implementation, the test should be standardized. Therefore, a physics reasoning ability test will be made by considering its validity and reliability as well as implementing equating.

A test consists of questions with a true or false answer [5] [6]. It functions to get a sample of individual behaviour. Multiple choice can also be understood as multiple questions that require test takers to answer or respond. The test aims to measure the extent to which test participants can reveal certain aspects of themselves.

In 1950, Dr George Rasch, a Danish mathematician, was faced with the analysis of exams for primary school students of different grades, but he used the same nonbased questions [7]. This raw score analysis led to a new finding. In case of the students' opportunity to answer that one item is similar to their ability compared to the difficulty level of the items, it can be written as the Rasch model having several advantages because it fulfils the five principles of the measurement model, namely: first, it can provide a linear scale with equal intervals; second, it can make predictions on missing data; third it can provide a more precise estimate; fourth, it can detect model inaccuracies; and fifth, it produces replicable measurements[8].
There are two types of equating checks, namely horizontal equating and vertical equating [9]. Horizontal equivalence is performed on scores of test instruments of the same difficulty level in groups of participants of the same level. During this time, a longitudinal equivalence was performed to reveal the development of students' abilities. Even though the students were at different levels, the instruments measured the same trait [10].

Vertical equating applied to different physical grade levels in high schools can help teachers gain a deeper understanding of students' development of physical skills after learning [10]. Information on student development can be used as a benchmark by which teachers determine the next steps and it can be used as an assessment document for teachers in improving classroom learning.

The method of mean \& sigma uses the mean and standard deviation of an anchor point. It is calculated based on the estimated location parameters (level of difficulty) [11]. The mean and standard deviation is calculated in the $\mathrm{m}$ parameter category and used to calculate the equating coefficients $\alpha$ and $\beta$ [12]. To produce equating constants $\alpha$ and $\beta$ in the mean $\&$ sigma method, it involves the mean and standard deviation of the difficulty index parameters from both tests [9]. Based on the equating model, the relationship between item difficulty index parameters is showing linear relationship [13][14]. The equating method is as follows

Vertical equating in different grades in high school physics subjects will help teachers have a better insight into the development of students' physical abilities after the learning process [6]. Information on student development of skills can be used by teachers as a reference to determine the next steps and can be used as an assessment for teachers to improve learning in class. Therefore, this article presents the portrait of high school students' physics competence with a vertical equating lens.

\section{METHOD}

\subsection{Data}

The data on physic competence in subjects were obtained from participants' answers to the questions in the ability test in physics subjects for grades X and XI students of high schools in Purworejo Regency. The physic competence test instrument in Physics subjects used a dichotomy model. A dichotomy model is a form of multiple choice used because this form is more objective and reliable in seeing student responses, without being influenced by the subjectivity of the raters [15]. The two test instruments used, namely class $\mathrm{X}$ and 
class XI test instruments contained the same items as anchor items.

\subsection{Method}

This study used the quantitative descriptive method. The population was the students of senior high schools in Purworejo district. The data were in the form of the students' responses to the reasoning ability tests on the physics course. The research sample was 352 grade $\mathrm{X}$ students and 352 grade XI students established using the stratified proportional random sampling technique. The instruments were two sets of physics subject tests in the form of objective tests with five answer choices and using an anchor of $25 \%$. The data in the form of scores were processed and assimilated using common sets of non-equivalent items designs with mean \& sigma equating methods based on the model of Rasch item approach. The test item characteristics were analysed with Winstep software 3.73. The results of the next test were used to know the development of students' physical abilities.

\section{RESULT AND DISCUSSION}

The vertical equating results with the item response theory approach (1PL) obtained the score of $\beta=-0.36$ so that the equation conversion of $\mathrm{X}$ grade test instrument to grade XI students was $b *=b 1-0.36$. The mean for the ability level of grade $X$ students was -1.42 (435 on the WITs scale) while the average score for the ability of grade XI students was -1.10 (450 on the WITs scale), meaning that the ability of the XI students is greater than that of grade XI students. Based on the results above, it can be concluded that there is an increase in the students' ability although the increase is not significant.

Table 1. Equation anchor test for $\mathrm{X}$ to $\mathrm{XI}$ grade

\begin{tabular}{|c|c|c|c|}
\hline \multirow{2}{*}{ No. } & X Dif level & \multirow{2}{*}{ No. } & Y \\
& $\begin{array}{c}\text { Test of } \mathrm{X} \text { ) } \\
\end{array}$ & & $\begin{array}{c}\text { (Anchor } \\
\text { Test of XI) }\end{array}$ \\
\hline 31 & -0.72 & 1 & -0.88 \\
\hline 32 & -0.53 & 2 & -1.49 \\
\hline 33 & -0.87 & 3 & -1.03 \\
\hline 34 & -0.56 & 4 & -1.26 \\
\hline 35 & -0.28 & 5 & -0.36 \\
\hline 36 & 0.17 & 6 & -0.85 \\
\hline 37 & 0.45 & 7 & 0.03 \\
\hline 38 & 1.01 & 8 & 0.76 \\
\hline 39 & -0.01 & 9 & -0.29 \\
\hline 40 & -0.05 & 10 & 0.35 \\
\hline $\mathrm{b}_{1}$ & -0.14 & $\mathrm{~b}_{2}$ & -0.50 \\
\hline $\mathrm{S}_{1}$ & 0.58 & $\mathrm{~S}_{2}$ & 0.73 \\
\hline
\end{tabular}

Table 2. Summary of equating conversion results

\begin{tabular}{|l|l|l|l|l|}
\hline Explanation & $\mathrm{X}\left(\mathrm{Y}^{*}\right)$ & $\mathrm{XI}(\mathrm{Y})$ & $\mathrm{X}\left(\mathrm{Y}^{*}\right)$ & $\mathrm{XI}(\mathrm{Y})$ \\
\hline Pers & 352 & 352 & 352 & 352 \\
\hline Item & 40 & 40 & 40 & 40 \\
\hline$\theta$ & -1.42 & -1.10 & 436 & 450 \\
\hline$\theta$ Highest & 1.96 & 1.33 & 589 & 560 \\
\hline$\theta$ Lowest & $-4,16$ & -3.11 & 311 & 359 \\
\hline Stan dev of & 0.90 & 0.64 & 41 & 29 \\
\hline
\end{tabular}

Based on the research results, it can be concluded that the development of skills in physics increased although it was not significant. Therefore, it becomes challenging homework for the teacher, in case of some materials that need deeper understanding among the students. The office of education, regarding the results of this study, can determine the development of physical skills in high school students. It can be used as a reference to arrange physics material for senior high students to make sure the material is mutually sustainable among levels. In so doing, the development of students' competence can be measured accurately [16]. However, the results of this study still have some limitation since the focus is only from the cognitive aspect. It can be more complete if affective and psychomotor aspects are also included

\section{CONCLUSION}

The conclusion of the results of this study is used as an input for teachers. Improving themselves concerning the teaching that has been done and the achievement that students have made by paying attention to appropriate learning methods and student motivation to improve student physics learning achievement.

\section{ACKNOWLEDGMENTS}

This research is fully supported by Yogyakarta State University.

\section{REFERENCES}

[1] S. R. Apresian, Arus bebas tenaga kerja dalam era masyarakat ekonomi ASEAN: Ancaman bagi Indonesia?, Indones. Perspect., vol. 1. no. 2, pp. 15-29, 2016.

[2] Pusat Penilaian Pendidikan, Laporan pengolahan UN tahun ajaran 2015/2016. Jakarta: Puspendik, 2016.

[3] E. L. Chiapetta and R. kobala Thomas, Science instruction in the midlle and secondary school. New York: Macmillan Publishing Company., 2010.

[4] H. Fatmawati, Analisis berpikir kritis siswa dalam pemecahan masalah matematika berdasarkan polya 
pada pokok bahasan persamaan kuadrat, J. Elektron. Pembelajaran Mat., vol. 2, no. 9, pp. 911-922, 2014.

[5] B. Harjo, E. Yogyakarta, B. Kartowagiran, and A. Mahmudi, International Journal of Instruction, vol. 12, no. 4, pp. 149-166, 2019.

[6] M. Allen and W. Yen, Introduction to measurement theory, Monterery: Brook/Cole Publishing Company, 1979.

[7] S.-H. Shin, How to treat omitted responses in rasch model-based equating, Pract. Assessment, Res. Eval., vol. 14, no. 1. p. n1. 2009.

[8] B. Sumintono and Wahyu Widiarso, Aplikasi model rasch untuk penelitian Ilmu-ilmu social, Jakarta: TrimKom, 2014.

[9] R. K. Hambleton and H. Swaminathan, Item response thery principles and applications, Boston: Kluwer Nijhoff Publishng, 1985.

[10] L. Croker and J. Algina, Introduction to classical and modern test theory. New York: Holt, Rinehard and Winston Inc, 1986.

[11] N. S. Peterson and M. J. Kolen, Scalng, norming, and equating dalam R.L Linn (Eds) Educational Measurement. New York: Macmillan Publishing Company, 1989.

[12] İ. Uysal and S. Kilmen, Comparison of item response theory test equating methods for mixed format tests, vol. 8, no. 2, pp. 1-11. 2016.

[13] H. Retnawati, Teori respons butir dan penerapannya: Untuk peneliti, praktisi pengukuran dan pengujian, mahasiswa pascasarjana, pp. 15, 2014.

[14] A. A. P. Antara and B. Bastari, Penyetaraan vertikal dengan pendekatan klasik dan item response theory pada siswa sekolah dasar, J. Penelit. dan Eval. Pendidik., vol. 19, no. 1. pp. 1324, 2015, doi: 10.21831/pep.v19i1.4551.

[15] M. A. Mittelha??user, A. A. B??guin, and K. Sijtsma, The effect of differential motivation on irt linking, J. Educ. Meas., vol. 52, no. 3, pp. 339358, 2015, doi: 10.1111/jedm. 12080.

[16] W. Wang, K. Jin, X. Qiu, and L. Wang, Item response models for examinee-selected items, vol. 49, no. 4, pp. 419-445, 2012. 